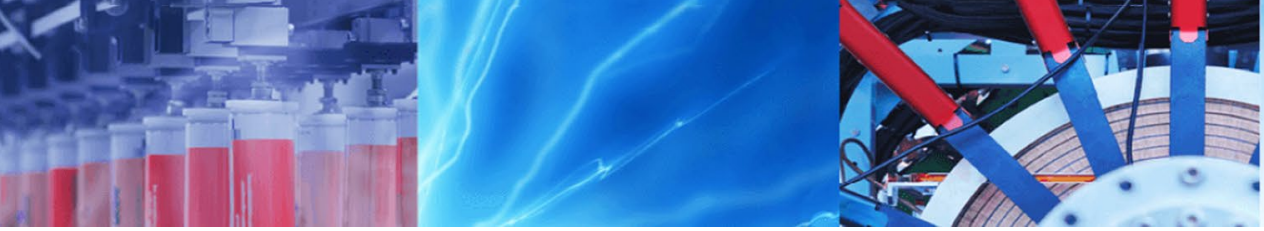

Research Article

\title{
Fracture analysis and in situ stress estimation of a gas condensate field in Persian Gulf using FMI and DSI image logs
}

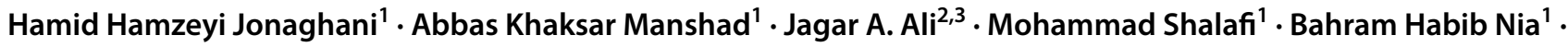 \\ Stefan Iglauer ${ }^{4} \cdot$ Alireza Keshavarz $^{4} \cdot$ Majid Akbari $^{1}$
}

Received: 7 August 2019 / Accepted: 3 October 2019 / Published online: 24 October 2019

(c) Springer Nature Switzerland AG 2019

\begin{abstract}
A giant gas field (called Field X in this study) in the Persian Gulf is located in the northern part of Qatar's North field was considered in this study. Since the reservoir subjected to a strong tectonic compression, an accurate estimation of in situ stresses is important for reservoir-related issues and stress-related geo-hazards, such as wellbore stability, well completion, drilling a horizontal well, and fracture conductivity in Kangan and Upper Dalan formations. The formation microimager (FMI) and dipole sonic imager (DSI), as effective borehole image techniques, were used for stress determination and borehole breakouts (BOs) and drilling-induced fractures (DIFs) detection in field X. Based on 10 DIFs and 65 BOs derived from FMI logs and measured velocities of P-wave and S-wave from DSI logs in 3 gas wells, in situ stresses were determined in different tectonic units. The orientations of the maximum and minimum horizontal stresses in well $B$ and well $C$ were identified to be NE-SW and NW-SE, respectively. Additionally, the value of minimum horizontal stress was varied from 6210 to 9664 psi, the maximum horizontal stress was ranged between 7124 and 9968 psi, and the vertical stress was gradually increased with the depth from 10,000 to 12,000 psi. Hence, according to the relationships between the in situ stresses $\left(\sigma_{v}>\sigma_{H \max }>\sigma_{\text {hmin }}\right)$, the tectonic stress regime of the studied area is normal.
\end{abstract}

Keywords In-situ stresses · Elastic moduli parameters · Borehole breakouts · FMI log · DSI log

\section{Introduction}

Understanding of the in situ stress is an important concern in oil and gas exploration and production, particularly, in borehole stability, reservoir drainage and flooding patterns, fluid flow in naturally-fractured reservoirs, hydraulic fracture stimulation, and seal breach by fault reactivation [33]. This stress can be described by estimating a stress tensor, which is simply consisting of four elements on the basis of the assumption that one principal stress acts vertically, such as the minimum horizontal stress, the maximum horizontal stress, the maximum horizontal stress orientation, and the magnitude of the vertical stress. [34, 35]. In last two decades, the estimation of the orientation of the maximum horizontal stress has received wide attention, especially in regards to the in situ stresses on subsurface fluid flow and fault reactivation [14].

The in situ stress can be measured using many techniques theoretically, experimentally and practically in site, such as acoustic emission, overcoring, stress restoration, focal-mechanism solution, borehole breakout, geological analysis, and hydraulic fracturing [28, 39, 41]. Since applications of overcoring and hydraulic fractures techniques are limited to a shallow depth [3] and their employment at great depth where severe breakouts, high pressures and high temperatures are exit is quite

$\triangle$ Abbas Khaksar Manshad, akmanshad113@gmail.com | 'Department of Petroleum Engineering, Abadan Faculty of Petroleum Engineering, Petroleum University of Technology (PUT), Abadan, Iran. ${ }^{2}$ Department of Petroleum Engineering, Faculty of Engineering, Soran University, Soran, Kurdistan Region, Iraq. ${ }^{3}$ Department of Petroleum Engineering, College of Engineering, Knowledge University, Erbil, Irbil, Iraq. ${ }^{4}$ School of Engineering, Edith Cowan University, Perth, WA 6027, Australia. 
difficult (Barton, [5], and meanwhile, focal mechanism is generally measures the stress data deeper than reservoir depth. Hence, the breakouts and drilling induced fractures (DIFs) are basically better indicators in aseismic regions and at intermediate depth [33]. From utilizing this approach, the majority of stress orientation indicators in the petroleum industry and geothermal systems can be obtained using televiewers and electrical imaging loggings [20]. As breakouts and drilling induced fractures techniques, the FMI image and DSI logs have been used to analyze the in situ stress in three wells in Field X. From utilizing the FMI log and on the basis of the electrical resistivity difference between layers, high resolution images are basically obtained from the wellbore $[16,26]$. In this way, various kinds of fractures with their detailed parameters including fracture direction and aperture can be detected in small scale phenomena in the wellbore $[16,26,33]$, which enables geologists to distinguish the field development studies [31]. Meanwhile, mechanical properties and stress profiles are detected using the DSI log which can be used to compute an in situ-stress profile [37].

In this study, we first reviewed the borehole imaging techniques provided Schlumberger company, and the principle of breakouts and drilling-induced fractures for stress determination described; then, we interpreted and analyzed the horizontal maximum stress orientation mainly using DSI imaging log in 3 gas wells in order to have a better understanding of structural geology in "X" field (Fig. 1).

\section{Geological setting}

The " $X$ " field, as a northern extension of Qatar's North Gas Field, is located in the Persian Gulf about $175 \mathrm{~km}$ from Kish Island and $105 \mathrm{~km}$ from Qatar [29] (Fig. 1). It is actually an integral part of the massive NNE-SSW trending Qatar Arch, which is one of the hugest known gas field in the world and contains about 14 trillions of cubic meters of proved gas reserve and 18 billion barrels of condensate gas [32]. Qatar Arch is located in the Arabian Plate platform in the Iranian territory and surrounded by the Zagros folded belt to the north and northeast. This field has been explored in 1990 by drilling well SP-01 that encountered huge gas reservoirs in the Kangan and Dalan formations [32]. Dalan and Kangan formations as the shallow marine carbonates are the essential reservoir units of field $X$, which are mainly deposited in Early Triassic and Late Permian ages, respectively $[15,25]$. These two formations together with the Khuff Formation as their equivalent in the North Field are identified to be formed reflecting a large tectono-eustatic occasion associated with the appearance of a sudden thermal subsidence of the earlier Neo-Tethys passive margin in Arabia and Iran, and the plunging of its rift shoulders [13].

The accumulation of gas in field $X$ is mainly bounded to the Permian and Triassic stratigraphical units that has become prospective in seventieth of last century following a great delineation of gas reserves [8]. The general form of Permian-Triassic stratigraphy of field $\mathrm{X}$ is presented in Fig. 2. In this gas field, the Late Permian to Early Triassic was divided into five unites; three units from the Late Permian (Upper and Lower Dalan), and two units from the Early

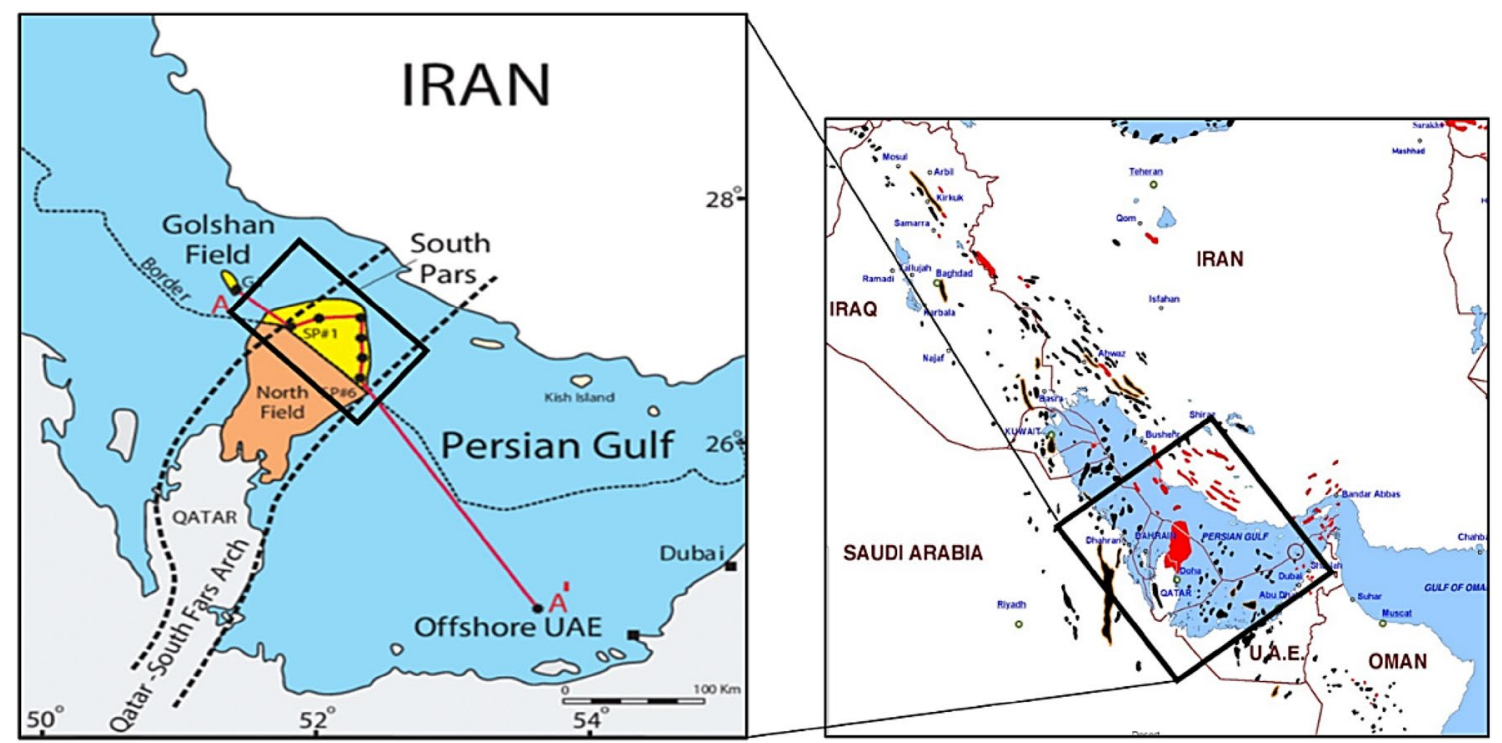

Fig. 1 Geographical and geological setting shows field X and main other hydrocarbon fields in Persian Gulf and adjacent areas 


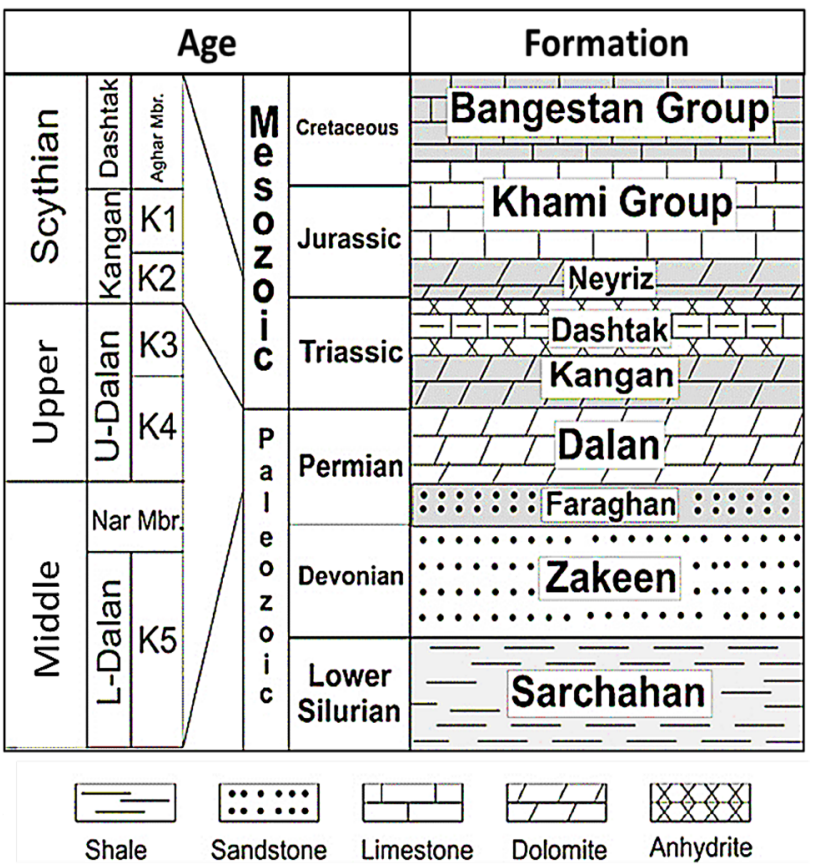

Fig. 2 Generalized stratigraphic chart of the field X presents formations, main lithology, the age and position of Kangan and Dalan [32]

Triassic (Kangan) [15]. The Dalan Formation was underlain by Faraghan Formation, which is subdivided into K5, K4 and $\mathrm{K} 3$ from bottom to the top, respectively (Fig. 2). K5 unit is mainly composed of dolomite with some Median Anhydrite intervals. While, anhydrite sets within the dolomite and limestone in $\mathrm{K} 4$ member. The succession is followed with the K3 unit that consists mostly of dolomite with lesser amounts of limestone. This uppermost Dalan Formation unit is overlain by another main reservoir unit, named Kangan, This Early Triassic Formation is subdivided into K2 unit (Limestones and dolomites) and K1 unit (anhydritic dolomite, dolomite and limestones). The Kangan Formation has been overlaid by as an efficient cap rock called Dashtak Formation [2, 9, 19]. According to RahimpourBonab [23] and [24], K2 and K4 units are the main reservoir intervals in the studied field. This lithological variation between limestone, dolomite and anhydrite made the South Pars to be is a good representative of heterogeneous carbonate-evaporite reservoirs in the world because of having lateral and vertical changes in the porosity types and ratios.

\section{Theory}

The in situ stress as important indicators of horizontal maximum stress orientation produces the wellbore enlargements, known as borehole breakouts [21]. The mechanism

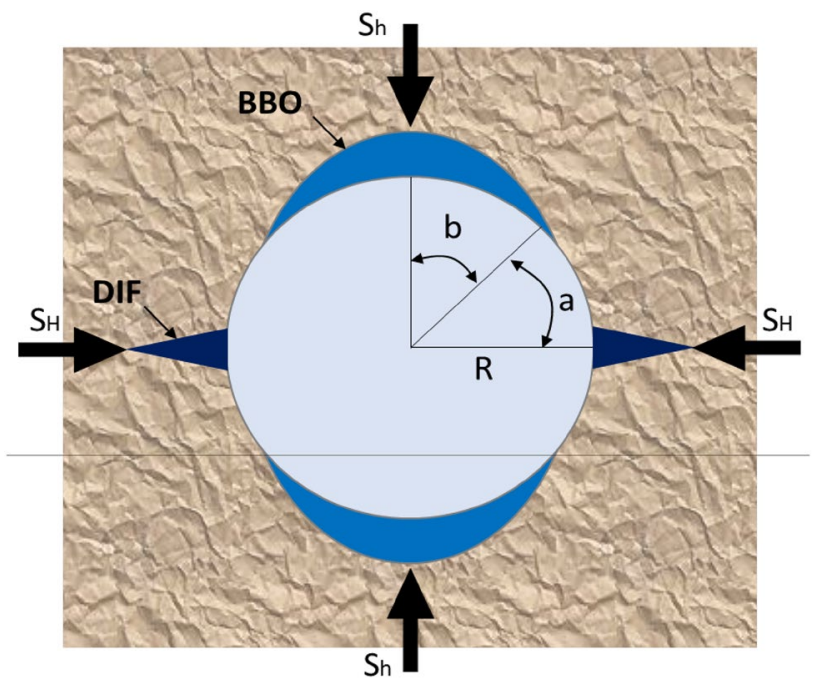

Fig. 3 The schematic cross-section showing the azimuth of breakout and drilling induced fracture; BBO (Breakout); DIF (drilling induced fracture); R (Radius); a (the angle with $S$ orientation); $b$ (the half width of the breakout)

of breakout formation was first described by $[6,7]$ and later, on the basis of theoretical studies and field trials, it has been extended and improved by [40]. In addition, [4] and [36] performed a laboratory test and indicated a borehole breakout at $420 \mathrm{~m}$ level in the Underground Research Laboratory (URL) field test. They identified that by having multiform of hydraulic pressure of drilling mud and instable crustal stress in various directions during drilling process, the compressive failure happens at the horizontal minimum stress direction (Fig. 3). Furthermore, Barton [5] and [38] stated that the stress magnitude can be calculated using borehole breakout in combination with other data.

There are two types of drilling-induced fractures; a thin, firmly, symmetrically associated fracture (DIFs-1) when the tensile strength around the wellbore was exceeded by the circumferential stress and the principal stress in parallel with the wellbore axis, and en-echelon fractures around the wellbore (DIFs-2), when the compressive rock strength has been surprised by circumferential stress which present lines $180^{\circ}$ offset at the borehole surface and oriented dependent on the wellbore axis [1]. According to [20], the induced fractures will be developed in S orientation in cases where the minimum stress concentration is allocated in the $\mathrm{S}_{\mathrm{H} \max }$ direction due to the fact that the tangential stress is equivalent to the minimum principle stress. 


\section{Data set and methods of work}

In this study, 3 wells (A, B and C) from the studied gas field were selected to be analyzed; the fullest of conventional logs including gamma ray, caliper, neutron, density, photoelectric effect and resistivity logs were collected from well A, the Formation Microimager (FMI) logs of wells B and $C$ were obtained from Schlumberger Company, and Baker Atlas company provided the Dipole Sonic Imager (DSI) of well A. All the stages of processing and interpretation of FMI, DSI and fullset logs have been conducted using GEOLOG software from Paradigm Company. Four geological zones; $\mathrm{K} 1$ and $\mathrm{K} 2$ from Kangan Formation, and $\mathrm{K} 3$ and $\mathrm{K} 4$ from the Upper Dalan Formation in Field $\mathrm{X}$ were investigated (Fig. 2). Firstly, the petrophysical analysis was conducted using the conventional well logs for estimating the lithology and fluid saturation of the studied interval. Thus, the available logs were corrected environmentally, and used in a probabilistic method for determining mineral volumes, porosity, and fluid volumes in various units of Kangan and Upper Dalan formations [17]. According to [22], MULTIMIN as a most accurate and common method based on several statistics and probability equations was used in this study.

Borehole imaging logs are used in this study to determine and evaluate the orientation and magnitude of the in situ stress in the field $\mathrm{X}$ including microresistivity by FMI and DSI log. Figure 4 shows the standardized processing steps of the FMI log measurement including the quality control, the speed correction, normalization and image creation. The FMI, with two electrode arrangement versions, provided the images of the wall of the borehole with unprecedented borehole coverage at a resolution of 0.2 in and $3 / 4$ borehole coverage [30]. The FMI pads were forced

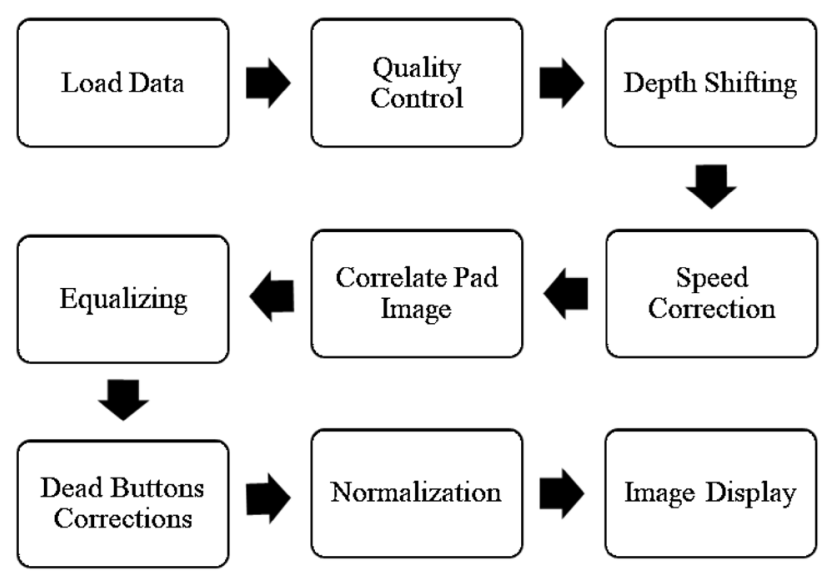

Fig. 4 Schematic flowchart illustrates image processing steps of FMI

\section{SN Applied Sciences}

against the borehole wall, after elevating the equipment upward. Then, the bottom electrodes discharge the current that has been received from the circuit, and this current was processed from the office of the well-site surface acquisition system through wirelines [27]. Additionally, imaging techniques using water-based mud are gradually adopted, especially in $\mathrm{K} 1, \mathrm{~K} 2, \mathrm{~K} 3$, and $\mathrm{K} 4$ zones of Dalan and Kangan Formations for reducing wellbore stability problems.

Furthermore, DSI log composed of a single monopole and double dipole transducers was used to estimate the compressional, stoneley and shear details of the studied section. From the estimated slowness of these waves, the elastic moduli including the Poisson's ratio, shear modulus, bulk modulus and young modulus were determined depending on velocities and density of $P$ and $S$ waves of studied layers [18]. The major steps of processing of DSI log are schematically illustrated in Fig. 5.

\section{Elastic moduli}

Shear modulus, Poisson's ratio, bulk modulus and young modulus were calculated using the below Eqs. (1-4) [12].

$\mu=\rho V_{s}^{2}$

$\theta=\frac{\left(V_{p}^{2}-V_{s}^{2}\right)}{2\left(V_{p}^{2}-V_{s}^{2}\right)}$

$K=\rho\left(V_{p}^{2}-4 / 3 V_{s}^{2}\right)$

$E=\frac{\rho V_{s}^{2}\left(2 V_{p}^{2}-4 V_{s}^{2}\right)}{\left(V_{p}^{2}-V_{s}^{2}\right)}$

where $V_{s}$ is the velocity of the shear wave, $V_{p}$ is the velocity of the compressional wave, $\rho$ is the density of layers, $\mu$ is

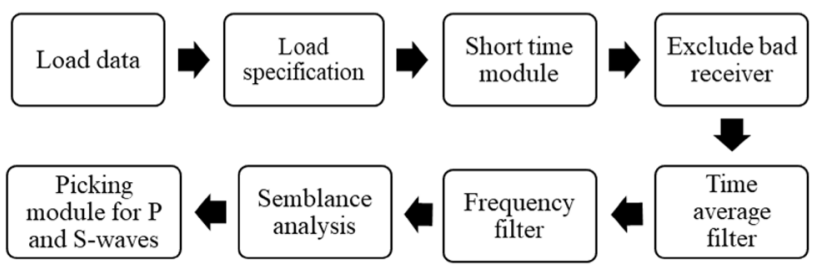

Fig. 5 Schematic flowchart presents image processing steps of DSI 
the shear modulus, $\theta$ is the Poisson's ratio, $E$ is the young modulus, and $\mathrm{K}$ is the bulk modulus.

\subsection{In-situ stresses}

Vertical stress $\left(\sigma_{v}\right)$ is formed from the overburden pressure which relies on the density and depth of the formation. For a situation of varying density with depth, the integration needs to be taken for densities of overlying rocks. The density of the overlying layers is determined by conducting a density log from the target interval to the surface. In petroleum exploration, according to [10] the density gradient for the depths of interest ranged between 0.8 and $1.0 \mathrm{psi} /$ $\mathrm{ft}$. the vertical stress is usually seen alone and presumed as a principal stress. This stress can be determined using the following equation:

$\sigma_{v}=\rho g h$

where $\rho$ is the density of the material, $g$ is the acceleration of gravity, $\mathrm{h}$ is the depth.

In isotropically and tectonically relaxed areas, the minimum and maximum horizontal stresses are the same. However, the horizontal stresses are not equal where major faults or active tectonics exist, which is likely the case. In this study, the (was used to determine. Formulations of this model are expressed as

According to $[4,21]$, the minimum and maximum horizontal stresses are equal in homogenous formations. However, they are not similar in a highly fractured formations, thus, the amounts of the minimum and maximum horizontal stresses have been estimated using poro-elastic horizontal strain model [10], as formulated in Eqs. $(6,7)$.

$\sigma_{h}=\frac{\vartheta}{1-\vartheta} \sigma_{v}-\frac{\vartheta}{1-\vartheta} \alpha P_{p}+\alpha P_{p}+\frac{E}{1-\vartheta^{2}} \varepsilon_{x}+\frac{\vartheta E}{1-\vartheta^{2}} \varepsilon_{y}$

$\sigma_{H}=\frac{\vartheta}{1-\vartheta} \sigma_{v}-\frac{\vartheta}{1-\vartheta} \alpha P_{p}+\alpha P_{p}+\frac{E}{1-\vartheta^{2}} \varepsilon_{y}+\frac{\vartheta E}{1-\vartheta^{2}} \varepsilon_{x}$

where $\sigma_{\mathrm{h}}$ and $\sigma_{\mathrm{H}}$ are the minimum and maximum horizontal stresses, respectively, $\vartheta$ is the Poisson's ratio, $\alpha$ is the
Biot's coefficient, $P_{p}$ is the pore pressure, $E$ is the Young's modulus and $\varepsilon_{\mathrm{x}}$ and $\varepsilon_{\mathrm{y}}$ are the strain in directions $\mathrm{x}$ and $\mathrm{y}$ respectively.

\section{Results and discussion}

\subsection{Petrophysical analysis}

Geological information of the region shows that the studied interval is divided two formations and four units including $\mathrm{K} 1$ and $\mathrm{K} 2$ within the Kangan formation and $\mathrm{K} 3$ and K4. From using the petrophysical logs, such as gamma rays, photoelectric factors, resistivity, acoustic and neutron logs, the depth intervals, lithology, effective porosity and water saturation of all units were determined as shown in Table 1. The total interval of Kangan formation was about $146 \mathrm{~m}$ which divided in $100 \mathrm{~m} \mathrm{~K} 1$ and $46 \mathrm{~m} \mathrm{~K} 2$ units. While, the studied interval of the Upper Dalan was about $214 \mathrm{~m}$ (119 m K3 and $95 \mathrm{~m} \mathrm{K4}$ ). As it can be seen, there is variations in petrophysical characteristics between the four studied members and better reservoir quality was identified within unit K4. In this zone, the measured porosity and water saturation were about $14.3 \%$ and $20.3 \%$, respectively, with a net to gross about $90 \%$. However, in the upper unit (K1) the net/gross was about $28 \%$, porosity about $9 \%$ and water saturation was $60 \%$, which indicates poor specifications compared to other units.

The log data were analyzed and evaluated using the MULTIMIN interpretation method for all formation units in well A [29]. Generally, the amount of shale has been neglected due to its low percentages from the gamma ray $(G R) \log$ of $K 1, K 2, K 3$, and $K 4$ units. The shape of the borehole was also measured by a comparison between caliper log and bit size on the first log track; for example, this track shows a clear enlargement of the borehole from the depth of 2990-2946 m in unit K1 (Fig. 6). While, there were no such variations noticed between the caliper and bit sizes across the other studied units. In the second track the amounts of thorium (Th), uranium (U) and potassium $(\mathrm{K})$ are shown; the value of thorium is

Table 1 Deep seating details and their petrophysical characteristics of K1, K2, K3, and K4 members of the studied interval in well A

\begin{tabular}{|c|c|c|c|c|c|c|c|c|c|c|c|}
\hline \multirow[t]{2}{*}{ Formation } & \multirow[t]{2}{*}{ Zone } & \multicolumn{2}{|c|}{ Depth setting } & \multicolumn{2}{|c|}{ Thickness } & \multirow[b]{2}{*}{$\begin{array}{l}\text { Net/ } \\
\text { gross } \\
\text { (ratio) }\end{array}$} & \multicolumn{3}{|c|}{ Lithology portion } & \multirow[t]{2}{*}{ Porosity (\%) } & \multirow[t]{2}{*}{ Sw (\%) } \\
\hline & & Top (m) & Bottom $(\mathrm{m})$ & Net (m) & Gross (m) & & Anhydrite (\%) & Calcite (\%) & Dolomite (\%) & & \\
\hline \multirow[t]{2}{*}{ Knagan } & K1 & 2889 & 2989 & 100 & 41 & 0.41 & 23 & 31 & 39 & 11.4 & 38 \\
\hline & $\mathrm{K} 2$ & 2989 & 3036 & 46 & 31 & 0.68 & 00 & 91 & 02 & 10.4 & 11.2 \\
\hline \multirow[t]{2}{*}{ Upper Dalan } & K3 & 3036 & 3154 & 119 & 32 & 0.28 & 17 & 45 & 33 & 9.1 & 60 \\
\hline & K4 & 3154 & 3250 & 95 & 86 & 0.90 & 00 & 80 & 18 & 14.3 & 20.3 \\
\hline
\end{tabular}


Fig. 6 MULTIMIN interpretation of unit $\mathrm{K} 1$ in well $\mathrm{A}$ illustrates studied depth, borehole size, gamma ray logs, porosity logs, resistivity logs and lithology

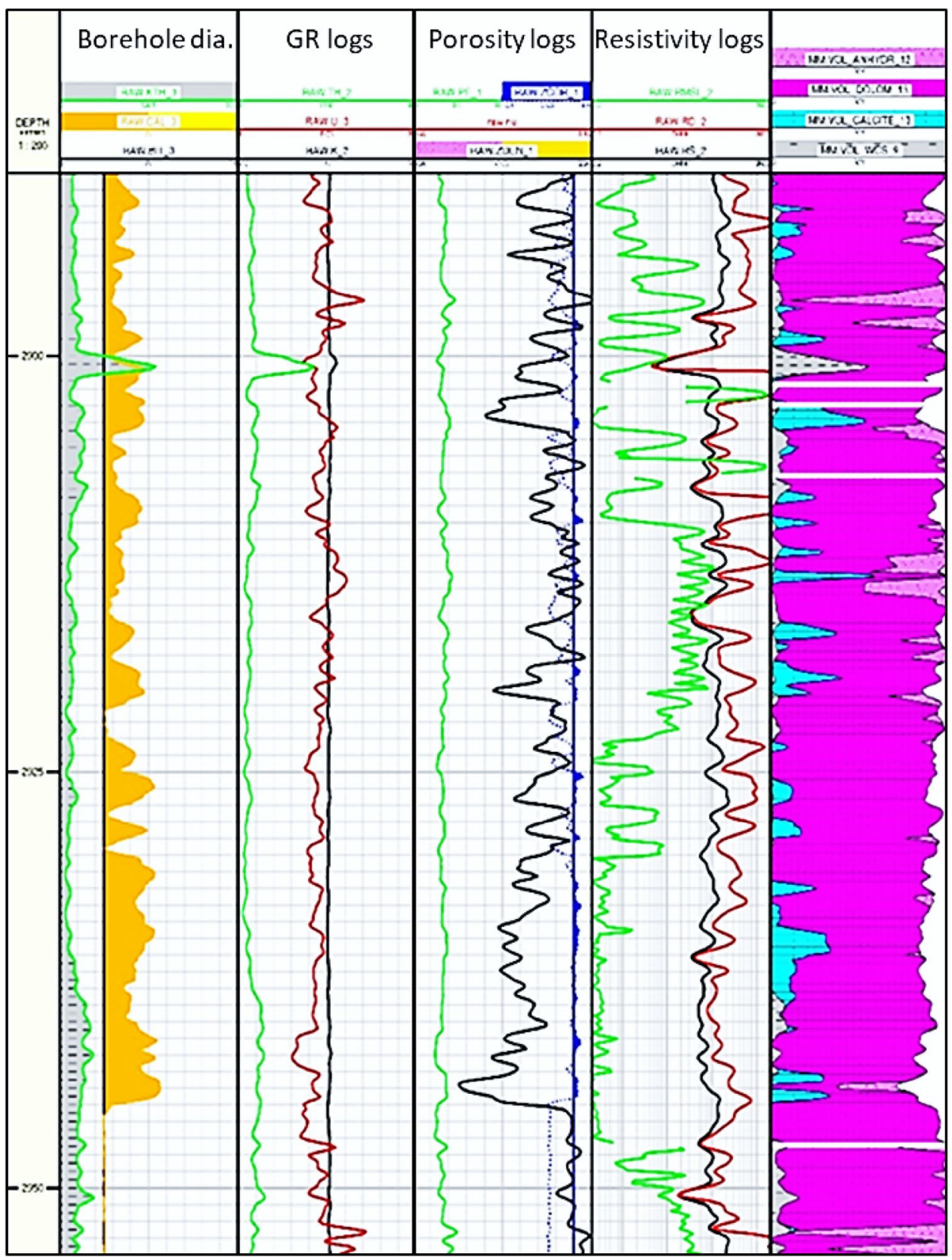

almost same in all units ranged between 1 and $2 \mathrm{ppm}$, uranium varied between 3 and $6 \mathrm{ppm}$, and amount of the potassium was about $0.5 \mathrm{wt} \%$ in the whole studied interval. The third track presents the neutron, density and photoelectric data; from having the neutron log placed to the right side of the density log, the sandstone lithology was found as shown between in a section between 2930 and $2945 \mathrm{~m}$ (Fig. 6), and the calcite was identified in an interval where no separation between density and neutron logs happened. Resistivity logs (shallow, medium and deep) were plotted in fourth track. Both medium and deep logs have the close values but the shallow log showed lower values in $\mathrm{K} 1$ almost, $\mathrm{K} 2$ and $\mathrm{K} 3$ members, however, the values of these logs are almost the same in through the unit K4. The amounts of calcite, dolomite, anhydrite and shale are shown in the last track. Calcite, dolomite and anhydrite are the significant lithology in both studied formations. Anhydrite was only identified in units $\mathrm{K} 1$ and $\mathrm{K} 3$ with a ratio ranged from 17 to $23 \%$, nevertheless, $91 \%$ of $\mathrm{K} 2$ and $80 \%$ of K4 are calcite. The outputs of MULTIMIN interpretation of the unit $\mathrm{K} 1$ from the Kangan formation from 2889 to $2960 \mathrm{~m}$ as an example are shown in Fig. 6. 


\subsection{Formation micro-imager (FMI) log}

\subsubsection{Well B}

Borehole breakouts (BOs) are generally described as fractures occurred in around the borehole along the minimum horizontal stress $\left(\sigma_{h}\right)$. BOs are typically developed in an environment where the compressive rock strength around the wellbore is exceeded by a circumferential stress. However, exceeding the tensile strength of the wall of the wellbore by the circumferential stress will cause the drilling induced fractures (DIFs) to be introduced, which oriented parallel to the maximum horizontal stress $\left(\sigma_{H}\right)$. These kinds of fractures can be detected on image logs in a circle to the ellipse manner inside the wellbore, and the FMI image log was used in this study. Figure 7 illustrates some examples of $\mathrm{BO}$ s and DIFs occurred in well B. For all the traced $\mathrm{BO}$ on the image log, the magnitude and azimuth of the dip were determined, and it was identified that the length of traces are not equal. Overall, 49 borehole breakouts were detected on the FMI image over the studied interval as shown in Table 2. 23 BOs were observed in the Kangan formation, which divided into $13 \mathrm{BO}$ in unit $\mathrm{K} 1$ and $10 \mathrm{BO}$ in unit K2. While, more BOs were occurred in the Upper Dalan Formation; 19 BOs in unit K3 and 7 BOs in unit K4.
Fig. 7 A typical breakout and DIF observed on an FMI log in well B; a FMI image shows the breakout identified as a pair of poorly resolved conductive zone at $3245.5 \mathrm{~m}$ and caliper logs $C 1$ and $C 2$ with enlargemnet, b Orientation of borehole breakouts, c FMI image shows the DIFs observed at 3135.5 and $3136.1 \mathrm{~m}$ and caliper logs C1 and $\mathrm{C} 2$, and $\mathbf{d}$ orientation of developed DIFs (a)

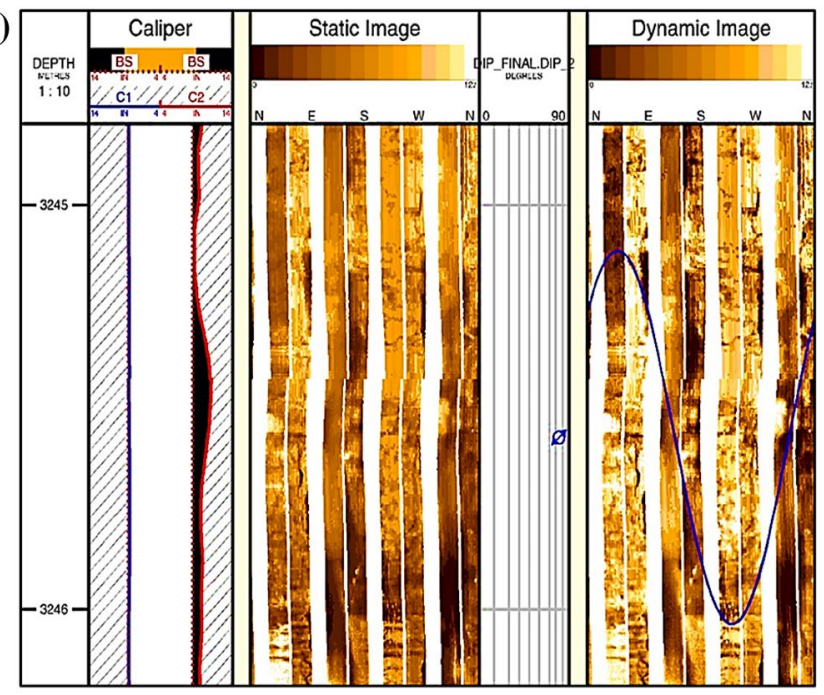

(c)

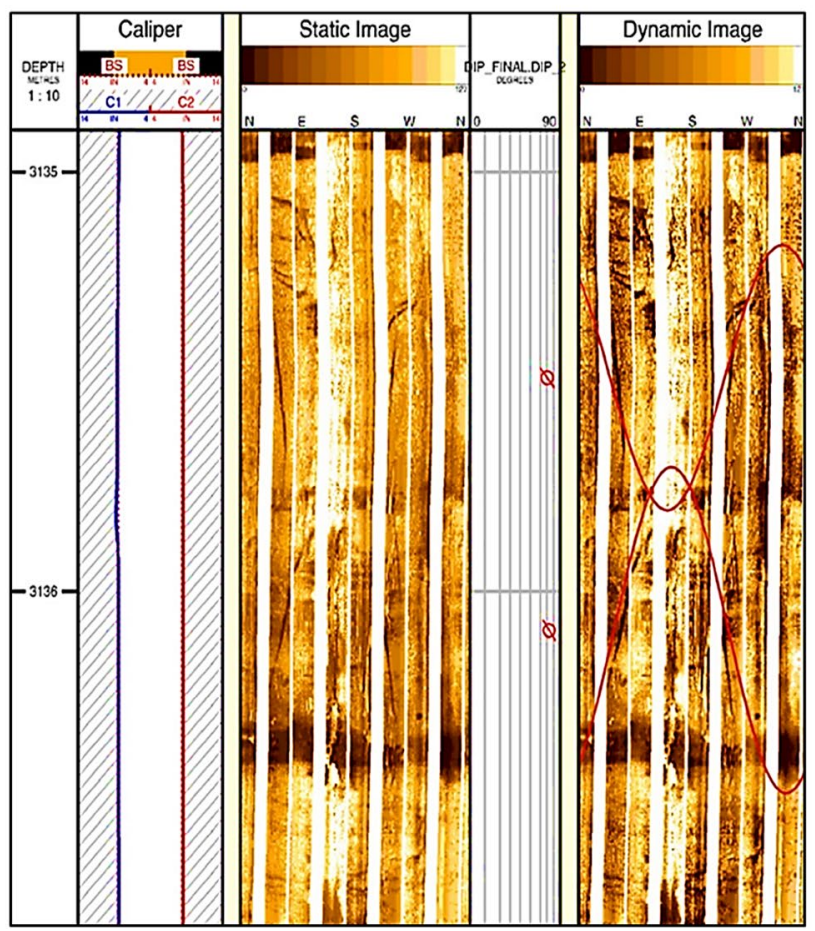

(b)

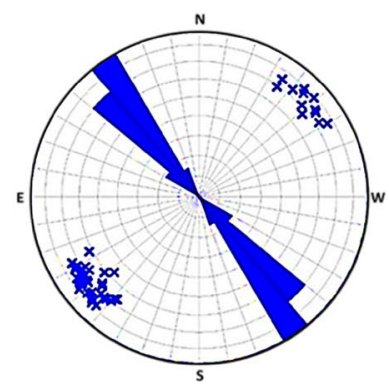

(d)

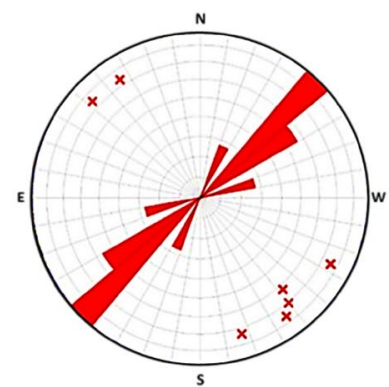

SN Applied Sciences A SPRINGER NATURE journa 
Table 2 Results of BOs analysis in Kangan and Upper Dalan formations in well $B$

\begin{tabular}{|c|c|c|c|c|c|}
\hline Formation & Unit & Depth (m) & $\begin{array}{l}\text { Caliper } 1 \\
\text { (in) }\end{array}$ & $\begin{array}{l}\text { Caliper } 2 \\
\text { (in) }\end{array}$ & $\begin{array}{l}\text { DIP of BO } \\
\text { (degrees) }\end{array}$ \\
\hline \multirow[t]{23}{*}{ Kangan } & \multirow[t]{13}{*}{ K1 } & 2865.9 & 10.44 & 8.62 & 67.82 \\
\hline & & 2871.4 & 8.50 & 8.72 & 75.39 \\
\hline & & 2886.6 & 8.51 & 8.70 & 67.01 \\
\hline & & 2897.1 & 8.44 & 8.74 & 73.51 \\
\hline & & 2910.6 & 8.37 & 9.57 & 73.65 \\
\hline & & 2911.6 & 8.30 & 9.73 & 70.2 \\
\hline & & 2913.2 & 8.37 & 9.78 & 61.78 \\
\hline & & 2918.2 & 8.36 & 10.54 & 71.91 \\
\hline & & 2921.0 & 8.40 & 9.80 & 77.80 \\
\hline & & 2923.0 & 8.41 & 9.42 & 73.92 \\
\hline & & 2942.8 & 8.43 & 8.56 & 74.83 \\
\hline & & 2950.2 & 8.41 & 8.72 & 74.19 \\
\hline & & 2966.1 & 8.41 & 8.56 & 76.32 \\
\hline & \multirow[t]{10}{*}{ K2 } & 2968.4 & 8.41 & 8.56 & 74.69 \\
\hline & & 3003.2 & 8.41 & 8.95 & 72.99 \\
\hline & & 3007.7 & 8.41 & 8.74 & 78.33 \\
\hline & & 3009.7 & 8.41 & 9.36 & 79.01 \\
\hline & & 3011.4 & 8.43 & 9.07 & 75.49 \\
\hline & & 3022.0 & 8.41 & 8.64 & 67.13 \\
\hline & & 3023.5 & 8.41 & 8.95 & 76.63 \\
\hline & & 3027.2 & 8.41 & 10.71 & 74.85 \\
\hline & & 3033.8 & 8.15 & 10.61 & 71.61 \\
\hline & & 3035.0 & 8.41 & 10.46 & 71.95 \\
\hline \multirow{14}{*}{$\begin{array}{l}\text { Upper } \\
\text { Dalan }\end{array}$} & \multirow[t]{14}{*}{ K3 } & 3036.4 & 8.39 & 9.43 & 72.02 \\
\hline & & 3044.7 & 11.39 & 8.56 & 60.98 \\
\hline & & 3046.6 & 10.75 & 8.45 & 78.23 \\
\hline & & 3048.8 & 10.35 & 8.22 & 67.06 \\
\hline & & 3057.8 & 8.41 & 9.51 & 72.49 \\
\hline & & 3058.4 & 8.44 & 9.07 & 70.56 \\
\hline & & 3060.1 & 8.43 & 9.67 & 67.38 \\
\hline & & 3065.0 & 9.55 & 8.66 & 76.35 \\
\hline & & 3065.7 & 9.47 & 8.54 & 69.11 \\
\hline & & 3066.4 & 9.64 & 8.56 & 67.87 \\
\hline & & 3066.9 & 9.53 & 8.51 & 56.91 \\
\hline & & 3067.8 & 9.65 & 8.53 & 70.62 \\
\hline & & 3096.8 & 9.05 & 8.56 & 71.53 \\
\hline & & 3108.8 & 8.46 & 8.60 & 70.68 \\
\hline
\end{tabular}

Table 2 (continued)

\begin{tabular}{|c|c|c|c|c|c|}
\hline Formation & Unit & Depth (m) & $\begin{array}{l}\text { Caliper } 1 \\
\text { (in) }\end{array}$ & $\begin{array}{l}\text { Caliper } 2 \\
\text { (in) }\end{array}$ & $\begin{array}{l}\text { DIP of BO } \\
\text { (degrees) }\end{array}$ \\
\hline & \multirow{12}{*}{ K4 } & 3114.8 & 9.46 & 8.42 & 70.82 \\
\hline & & 3117.8 & 8.46 & 8.61 & 76.14 \\
\hline & & 3120.3 & 8.46 & 8.64 & 70.96 \\
\hline & & 3122.2 & 8.46 & 8.64 & 76.43 \\
\hline & & 3127.1 & 8.41 & 9.73 & 73.72 \\
\hline & & 3191.5 & 8.41 & 9.31 & 65.92 \\
\hline & & 3192.2 & 8.34 & 9.26 & 75.73 \\
\hline & & 3201.5 & 8.21 & 8.48 & 69.75 \\
\hline & & 3245.6 & 8.38 & 11.04 & 74.85 \\
\hline & & 3254.2 & 8.27 & 10.58 & 78.44 \\
\hline & & 3256.9 & 8.51 & 8.53 & 76.16 \\
\hline & & 3279.6 & 8.39 & 9.17 & 71.88 \\
\hline
\end{tabular}

Figure 7a presents an example of these features at $3245.5 \mathrm{~m}$ of FMI image. In the same depth, the enlargement in wellbore diameter on caliper $\log \mathrm{C} 2$, and a poorly resolved conductive zone on the FMI image were observed. Additionally, as shown in Fig. 7b, the strike feature of the traced BOs is in N45W-S45E direction, which indicates that the orientation of minimum horizontal stress $\left(\sigma_{\mathrm{Hmin}}\right)$ around well $\mathrm{B}$ is in NW-SE, and is perpendicular to drilling induced fractures. The mean dip of the BOs in this well is about $75.33^{\circ}$ with the standard deviation 2.73 .

Furthermore, seven DIFs were identified by FMI image $\log$ as shown in Table 3. All the fractures were induced below $3135 \mathrm{~m}$ within the Upper Dallan formation in units $\mathrm{K} 3$ and mostly K4. Figure 7c shows two of these induced fractures at 3135.5 and $3136.1 \mathrm{~m}$ which formed in unit $\mathrm{K} 3$. DIFs were developed along N45E-S45W direction of the borehole, which can be considered as the direction of the maximum horizontal in situ stress $\left(\sigma_{\mathrm{Hmax}}\right)$ with the mean dip about $72.30^{\circ}$ (Fig. 7d).

Table 3 Results of DIF analysis in Upper Dalan formations in well B

\begin{tabular}{llll}
\hline Formation & Unit & Depth $(\mathrm{m})$ & $\begin{array}{l}\text { Dip of DIF } \\
\text { (degrees) }\end{array}$ \\
\hline Upper Dalan & K3 & 3135.49 & 70.51 \\
& \multirow{2}{*}{ K4 } & 3136.09 & 73.53 \\
& 3171.28 & 74.51 \\
& 3184.91 & 73.36 \\
& 3204.10 & 62.48 \\
& 3205.15 & 75.95 \\
& 3206.41 & 75.79 \\
\hline
\end{tabular}




\subsubsection{Well C}

In this stduy for otaining more detils on borehole breakouts and drilling induced fractures, the FMI image log was also applied for well C. Figure 8 illustrates some examples of BOs and DIFs occurred in well C. For all the traced BOs on the image log, the magnitude and azimuth of the dip were determined, and it was identified that the length of traces are not equal.

A total of 16 borehole breakouts (BO) with an overall length of $874 \mathrm{~m}$ were interpreted in well C (Table 4). As it can be seen, no BO was identified across the unit $\mathrm{K} 3$ in Upper Dalan formation and most of the BOs were occurred in the unit $\mathrm{K} 1$ interval. The mean dip of $\mathrm{BO}$ s in this well is about $76.24^{\circ}$ with the standard deviation of 3.17. These features strike consistently in N3OW-S30E direction (Fig. 8b), which indicates that the orientation of minimum horizontal stress $\left(\sigma_{H \min }\right)$ around well $C$ appears to be NW-SE. Examples of these features can be seen at $2725.5 \mathrm{~m}$ in Fig. 8a.

Moreover, only three natural fractures were identified over the entire interval by FMI image log as shown in Table 5. All the fractures were induced below $3119 \mathrm{~m}$ within the Upper Dallan formation in units $\mathrm{K} 3$ and mostly K4. Figure $8 \mathrm{C}$ shows an example of these fractures at 3139.8 which formed in unit K4. The dip inclination of the identified fractures ranges from 74 to 79 degrees with an average of $76.14^{\circ}$ (Fig. 8d). These features strike consistently (a)

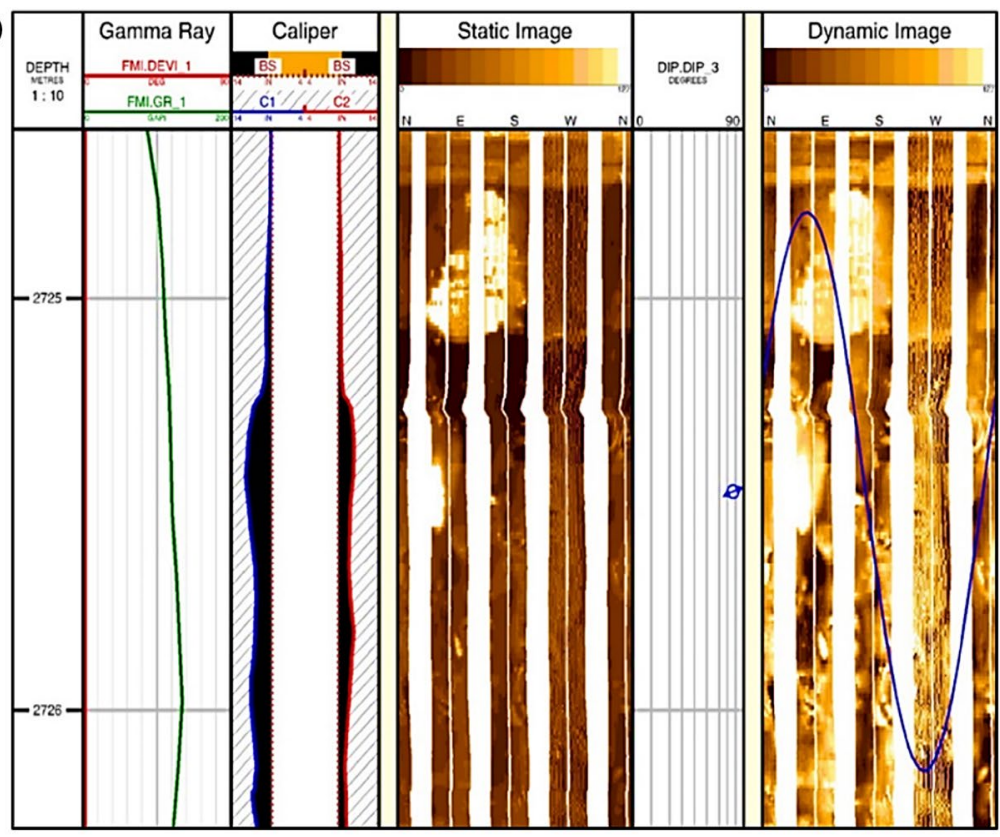

(c)

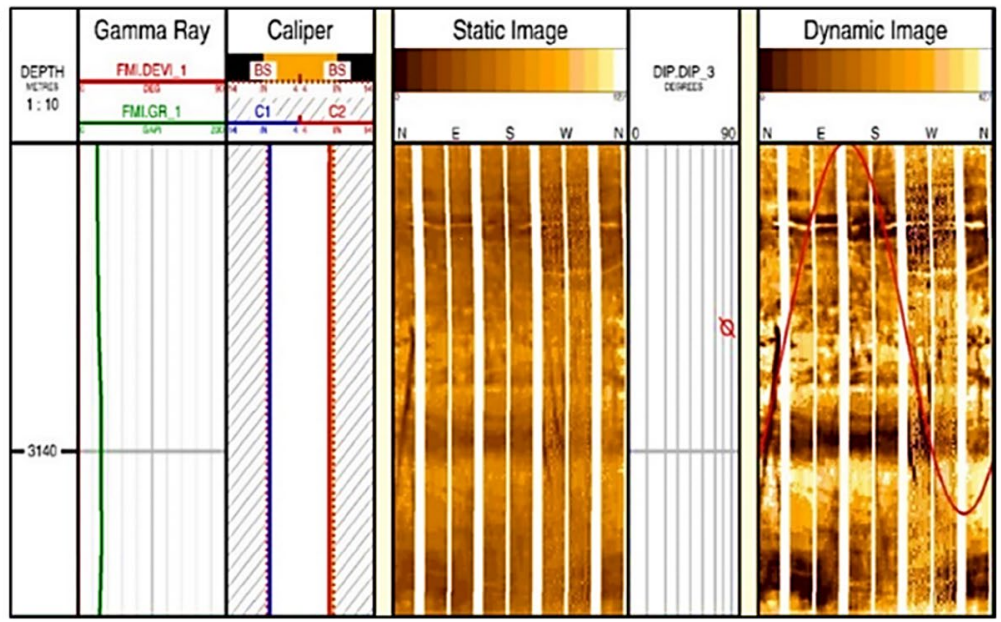

(b)

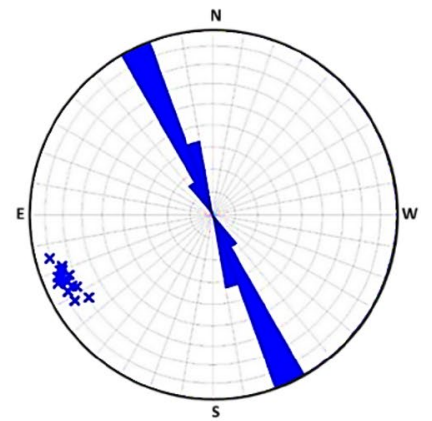

(d)

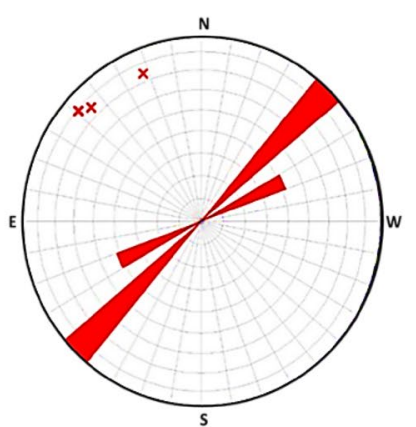

Fig. 8 A typical breakout and DIF observed on an FMI log in well C; a FMI image shows the breakout identified as a pair of poorly resolved conductive zone at $2725.5 \mathrm{~m}$ and caliper logs C1 and C2 with enlargemnet, b Orientation of BOs, c FMl image shows the fractrures observed at $3139.8 \mathrm{~m}$ and caliper logs $\mathrm{C} 1$ and $\mathrm{C} 2$, and $\mathbf{d}$ orientation of the natural fractures 
Table 4 Results of BOs analysis in Kangan and Upper Dalan formations in well $C$

\begin{tabular}{llllll}
\hline Formation & Unit & Depth $(\mathrm{m})$ & $\begin{array}{l}\text { Caliper 1 } \\
\text { (in) }\end{array}$ & $\begin{array}{l}\text { Caliper 2 } \\
\text { (in) }\end{array}$ & $\begin{array}{l}\text { DIP of BO } \\
\text { (Degree) }\end{array}$ \\
\hline Kangan & K1 & 2725.47 & 11.95 & 10.58 & 77.08 \\
& & 2728.24 & 10.32 & 8.67 & 75.92 \\
& & 2741.23 & 10.03 & 8.74 & 72.99 \\
& & 2755.74 & 8.76 & 8.45 & 79.20 \\
& & 2763.97 & 8.88 & 9.97 & 69.05 \\
& & 2958.52 & 9.60 & 8.52 & 71.75 \\
& & 2961.17 & 8.87 & 8.42 & 75.47 \\
& & 2978.02 & 9.26 & 8.42 & 73.85 \\
& & 2985.18 & 8.55 & 9.43 & 77.36 \\
& & 2986.43 & 8.55 & 8.42 & 74.90 \\
Upalan & 2996.63 & 8.55 & 8.42 & 80.43 \\
& & 3023.19 & 8.55 & 8.65 & 76.58 \\
& & 3161.02 & 9.72 & 8.15 & 75.45 \\
& 3166.69 & 8.81 & 8.15 & 80.33 \\
& & 3181.71 & 8.35 & 8.25 & 78.18 \\
& 3202.39 & 9.38 & 8.23 & 76.78 \\
\hline
\end{tabular}

Table 5 Results of DIF analysis in Upper Dalan formations in well C

\begin{tabular}{llll}
\hline Formation & Unit & Depth $(\mathrm{m})$ & $\begin{array}{l}\text { Dip of DIF } \\
\text { (degrees) }\end{array}$ \\
\hline Upper Dalan & K1 & 3119.03 & 74.26 \\
& K2 & 3135.99 & 79.16 \\
& & 3139.78 & 75.02 \\
\hline
\end{tabular}

in N60E-S60 W direction. Which can be considered as the direction of maximum horizontal in situ stress.

\subsection{Dipole sonic imager (DSI) log}

In this work, densities of layers were measured using the density log and DSI log was used to determine slowness of compressional and shear waves of all units in Kangan and Upper Dalan formations in well A. DSI log of the unit K1 from well $A$ as an example is shown in Fig. 9. In the figure, the monopole, projection and semblance are shown to describe the time to receive the data, average frequency used in filtering the data and presenting the pressure, shear and stonely waves [29].
From by applying Eqs. (1-4) to measured density and slowness of the $P$ and $S$ waves, the elastic parameters and in situ stresses were estimated for various depths across the studied sections as shown in Fig. 10. In the figure, the results of density log, shear modulus, P-wave modulus, Young's modulus, poison's modulus, uniaxial compressive strength (UCS), the maximum horizontal stress, pore pressure, the minimum horizontal stress and the vertical stress are shown from the left to right, respectively. As it can be seen, different values of densities were measured across the Kangan and Upper Dalan formations; the highest value was obtained from unites $\mathrm{K} 1$ and $\mathrm{K} 2$ which was about $2.95 \mathrm{gm} / \mathrm{cc}$. Although, the value of density was lower in K2 and K4 compared to other units. Static and dynamic results of shear, bulk, P-wave and S-wave parameters have the same trends as shown on second to fifth tracks, which they start with the moderate pressure and reduced through unit K4. However, the poison's ratio is the same in the all units ranged from 0.2 to 0.3 , and UCS is higher in units $\mathrm{K} 1$ and $\mathrm{K} 3$ compared to units $\mathrm{K} 2$ and $\mathrm{K} 4$.

Furthermore, the pore pressure (PP) and in situ stresses profiles are shown in the last track in Fig. 10. As it can be seen, the value of PP is slightly from the $\mathrm{K} 1$ to other units which was about 7370 psi and decreased to 3900 psi across K2, K3 and K4. However, the values of $\sigma_{h \min }$ and $\sigma_{H \max }$ are varied between 6210 and $9668 \mathrm{psi}$, and $\sigma_{v}$ was gradually increased with the depth from 10,000 to 12,000 psi. In this well, by comparing the in situ stresses estimated in four included unites in Dalan and Kangan formations, it was found that the order of magnitudes of in situ stresses is $\sigma_{v}>\sigma_{H \max }>\sigma_{h \min }$ which indicates that the normal fault is the dominant stress regime in this studied area [11]. Table 6 shows average values of in situ stresses for the studied four zones of Kangan and Upper Dalan formations.

\section{Conclusions}

This study focused on a detailed geomechanical analysis in the one of the largest gas field. Thus, we used different sets of data including conventional, FMI and DSI logs from three wells ( $A, B$ and $C$ ). The following major conclusions can be drawn based on the results obtained from this study: 
Fig. 9 DSI data shows monopole, projection and semblance of Kangan and Upper Dalan formations in well $A$

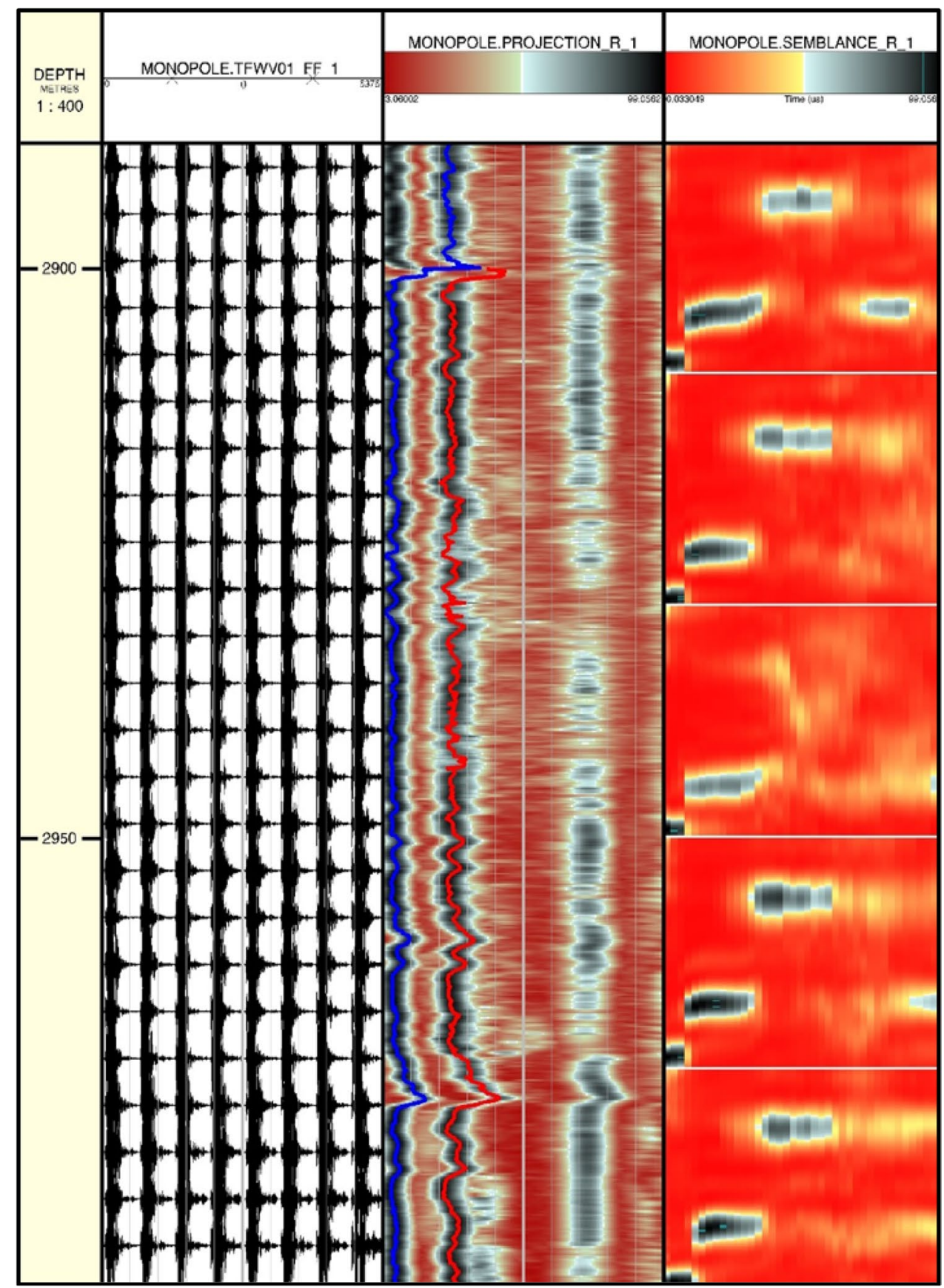

- The value of average porosity in K4 is greater compared to other zones, while the highest value of water saturation (about 60\%) was obtained in $\mathrm{K} 3$ and it was much lower in the other units.

- Anhydrite was only identified in units $\mathrm{K} 1$ and $\mathrm{K} 3$ with a ratio ranged from 17 to $23 \%$. However, $91 \%$ of K2 and $80 \%$ of $\mathrm{K} 4$ are calcite.

- Totally, 65 borehole breakouts in both wells B and C were identified with the average length of $1301 \mathrm{~m}$. The dip of BOs in well B is slightly lower than in well
C, which were about $75.33^{\circ}$ and $76.24^{\circ}$, respectively. While, 10 DIFs were observed in wells $B$ and $C$ with the dip of $72.30^{\circ}$ in well $B$ and $76.14^{\circ}$ in well $C$.

- The orientations of the maximum and minimum horizontal stresses in well $A$ and well $B$ was identified to be NE-SW and NW-SE, respectively.

- Elastic parameters were determined from measured values of P-wave and S-wave velocities obtained by DSI log in well A. 
Fig. 10 Density log, elastic moduli and in situ stresses of the four members of Dalan and Kangan formations

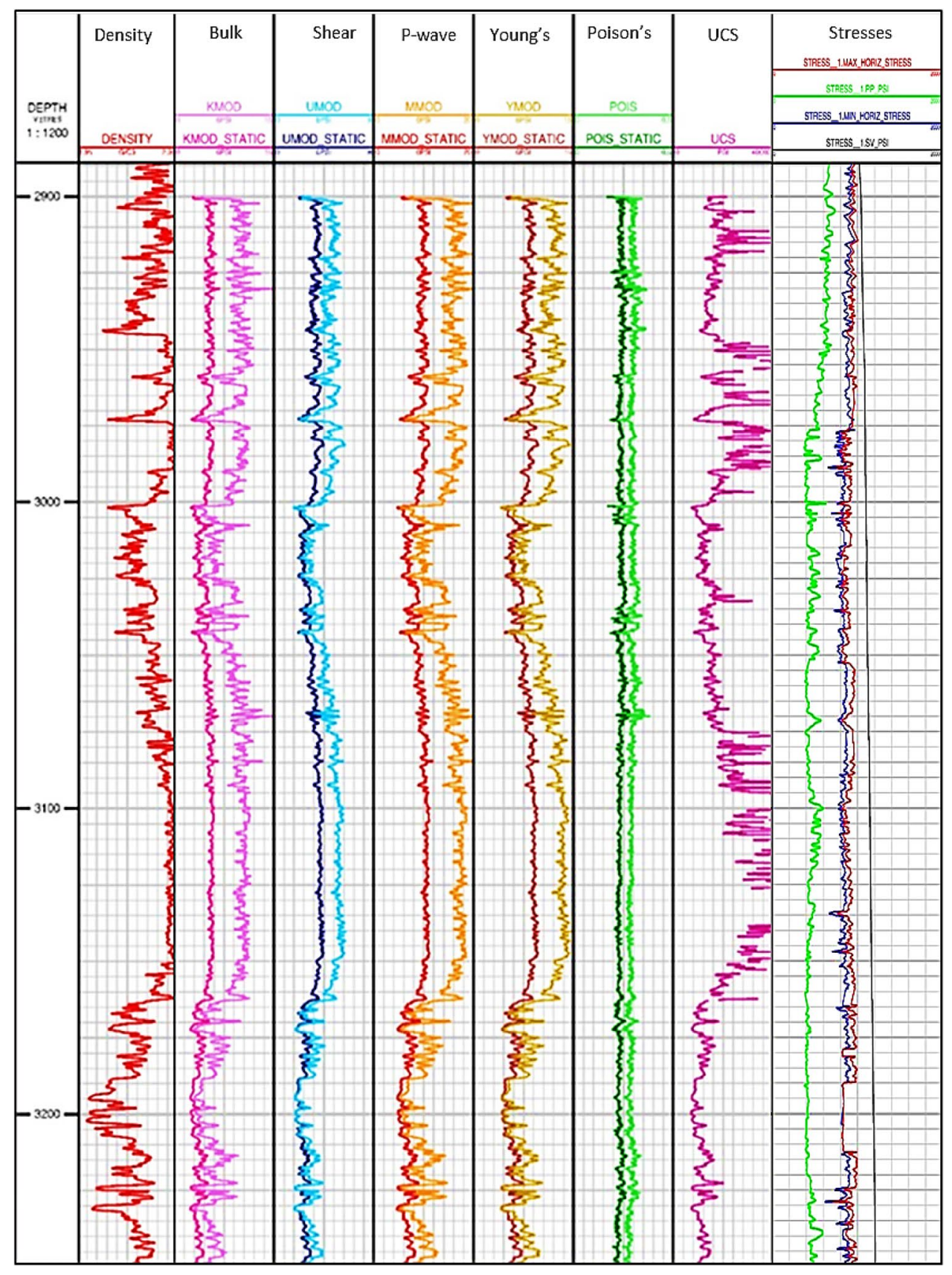

Table 6 Estimated values of in situ stresses in Kangan and Dalan formations

\begin{tabular}{llllll}
\hline Formation & Zone & Depth $(\mathrm{m})$ & $\sigma_{v}(\mathrm{psi})$ & $\sigma_{\text {Hmax }}(\mathrm{psi})$ & $\sigma_{\text {hmin }}(\mathrm{psi})$ \\
\hline Kangan & K1 & $2889-2989$ & 10,652 & 9322 & 8811 \\
& K2 & $2989-3035$ & 11,048 & 8774 & 8129 \\
\multirow{4}{*}{ Upper Dalan } & K3 & $3035-3154$ & 11,411 & 9033 & 8362 \\
& K4 & $3154-3249$ & 11,893 & 9151 & 8556 \\
\hline
\end{tabular}

- The relationships between the in situ stresses are $\sigma_{v}>\sigma_{\text {Hmax }}>\sigma_{h \text { min }}$, which indicates that the tectonic stress regime of the studied area is normal.

- The pore pressure ranged from 3900 to 7370 psi, the amount of minimum horizontal stress varies from 6210 to $9664 \mathrm{psi}$, and the maximum horizontal stress is ranged between 7124 and 9968 psi. 


\section{Compliance with ethical standards}

Conflict of interest The authors declare that there is no potential conflict of interest involved in the publication of this research article.

Informed consent The research involved no human participants and/ or animals.

\section{References}

1. Aadnoy BS, Bell JS (1998) Classification of drilling-induced fractures and their relationship to in situ stress directions. Log Anal 39:27-42

2. Aali J, Rahimpour-Bonab H, Kamali MR (2006) Geochemistry and origin of the world's largest gas field from Persian Gulf, Iran. J Pet Sci Eng 50:161-175

3. Ali AA, Stephen K (2018) A semi-analytical method for history matching and improving geological models of layered reservoirs: cgm analytical method. Chem Petrol Eng 52(1):69-80. https://doi.org/10.22059/jchpe.2018.252190.1220

4. Bagdeli M, Manshad AK, Shadizadeh SR, Ali JA, Gholami R, Keshavarz A, Iglauer S (2019) Natural fracture characterization and wellbore stability analysis of a highly fractured southwestern Iranian oilfield. Int J Rock Mech Min Sci 123(104):94-101. https ://doi.org/10.1016/j.ijrmms.2019.104101

5. Barton C (1998) Development of in situ stress measurement techniques for deep drillholes. A Diss. Submitt. Dep. Geophys. Comm. graduate students Stanford Univ. partial fulfillment Req. PhD degree 1-192

6. Bell JS, Gough DI (1979) Northeastesouthwest compressive stress in Alberta: evidence from oil wells. Earth Planet Sci Lett 45:475-482

7. Bell JS, Gough DI (1982) The use of borehole breakouts in the study of crusta stress. U S Geol Surv Open File Rep 82(1075):539-557

8. Bordnave ML (2008) The origin of the Permo-Triassic gas accumulations in the Iranian Zagros foldbelt and contiguous offshore area: a review of the Paleozoic petroleum system. J Pet Geol 31:3-42

9. Ehrenberg SN (2006) Porosity destruction in carbonate platforms. J Pet Geol 29:41-52

10. Fjaer E, Holt RM, Horsrud P, Raaen AM, Risnes R (2008) Petroleum related rock mechanics, 2nd edn. Elsevier, Amsterdam

11. Gholami R, Moradzadeh A, Rasouli V, Hanachi J (2014) Practical application of failure criteria in determining safe mud weight windows in drilling operations. J Rock Mech Geotech Eng. 6(1):13-25

12. Hudson JA, Harrison JP (1997) In situ stress. In: Engineering rock mechanics. Pergamon Oxford, pp 41-69. http://dx.doi. org/10.1016/B978-008043864-1/50005-7

13. Insalaco E, Virgone A, Courme B, Gaillot J, Kamali M, Moallemi A, Lotfpour M, Monibi S (2006) Upper Dalan Member and Kangan Formation between the Zagros Mountains and offshore Fars, Iran: depositional system, biostratigraphy and stratigraphic architecture. GeoArabia 11:75-176

14. Jones RM, Hillis RR (2003) An integrated, quantitative approach to assessing fault-seal risk. AAPG Bull 347:189-215

15. Kashfi MS (2000) Greater Persian Gulf permian-triassic stratigraphic nomenclature requires study. J Oil Gas Tulsa 6:36-44

16. Khoshbakht F, Memarian H, Mohammadnia M (2009) Comparison of Asmari Pabdeh and Gurpi formation's fractures, derived from image log. J Pet Sci Eng 67:65-74
17. Manshad AK, Jalalifar $H$, Aslannejad M (2014) Analysis of vertical, horizontal and deviated wellbores stability by analytical and numerical methods. J Pet Exp Prod Technol 4(4):359-369

18. Moatazedian I, Rahimpour-Bonab H, Kadkhodaie-Ilkhchi A, Rajoli M (2011) Prediction of shear and compressional wave velocities from petrophysical data utilizing genetic algorithms technique: a case study in Hendijan and Abuzar fields located in Persian Gulf. Geopersia 1:1-17

19. Moradpour M, Zamani Z, Moallemi SA (2008) Controls on reservoir quality in the Lower Triassic Kangan Formation, Southern Persian Gulf. J Pet Geol 31:367-386

20. Nian T, Wang G, Xiao C, Zhou L, Deng L, Li R (2016) The in situ stress determination from borehole image logs in the Kuqa Depression. J Nat Gas Sci Eng 34:1077-1084

21. Plumb RA, Hickman SH (1985) Stress-induced borehole elongation: a comparison between the four-arm dipmeter and the borehole eleviewer in the auburngeothermal well. J Geophys Res 90(B7):5513-5521

22. Rahim N, Watson N (2016) Determination of duvernay formation reservoir properties through probabilistic petrophysical analysis calibrated to core studies. Paper presented at Geoconvention, Calgary

23. Rahimpour-Bonab H (2007) A procedure for appraisal of a hydrocarbon reservoir continuity and quantification of its heterogeneity. J Pet Sci Eng 58:1-12

24. Rahimpour-Bonab H, Asadi-Eskandar A, Sonei A (2009) Controls of Permian-Triassic boundary over reservoir characteristics of south pars gas field, Persian Gulf. Geol J 44:341-364

25. Rahimpour-Bonab H, Esrafili-Dizaji B, Tavakoli V (2010) dolomitization and precipitation in permo-triassic carbonates at the South Pars gas field, offshore Iran: controls on reservoir quality. J Pet Geol 33(1):43-66

26. Rajabi M, Sherkati S, Bohloli B, Tingay M (2010) Subsurface fracture analysis and determination of in situ stress direction using FMI logs: an example from the Santonian carbonates (Ilam Formation) in the Abadan Plain, Iran. Tectonophysics 492:192-200

27. Robert L, Lozada GT, Perez FM, Cheung P, Hansen SM, Rosas AM (2011) A high deinition approach to formation imaging in wells drilled with nonconductive muds. In: SPWLA 52nd annual logging symposium, May 14-18, Colorado Springs, Colorado

28. Schmitt DR, Currie CA, Zhang L (2012) Crustal stress determination from boreholes and rock cores: fundamental principles. Tectonophysics 58:1-26

29. Shalafi M, Moradi S, Ghassem-Alaskari MK, Kazemi MS (2016) Drilling fluid loss control via implementing the FMI and DSI logs to protect environment. Model Earth Syst Environ 2(4):1-10

30. Schlumberger (2004) Schlumberger WTA marketing service: FMI fullbore formation microimager. Schlumberger Educational Services, Houston

31. Sun LP, Shou H, Zhao XL, Li P (2009) Sedimentary facies identification based on FMI imaging logging data. NCKI J 4(18):108-117

32. Tavakoli V, Rahimpour-Bonab H, Esrafili-Dizaji B (2011) Diagenetic controlled reservoir quality of South Pars gas field, an integrated approach. C R Geosci 343(1):55-71

33. Tingay MRP, Hillis RR, Morley CK, King RC, Swarbrick E, Damit AR (2009) Present-day stress and neotectonics of Brunei: implications for petroleum exploration and production. AAPG Bull 93(1):75-100

34. Tingay MRP, Morley CK, Hillis RR, Meyer J (2010) Present-day stress orientation in Thailand's basins. J Struct Geol 32:235-248

35. Tingay MRP, Morley CK, King RE, Hillis RR, Hall R, Coblentz D (2010) The southeast asian stress map. Tectonophysics 482:92-104

36. Villarroel FMG, Junior EVA, Rabello GF, Bloch M, Azevedo VA (2010) Breakouts:physical and numerical modeling. In: The SPE 
Europec/EAGE annual conference and exhibition, June 14-17, Barcelona, Spain

37. Wu HY, Ma KF, Zoback M, Boness $\mathrm{N}$, Ito $\mathrm{H}$, Hung JH, Hickman $S$ (2007) Stress orientations of Taiwan Chelungpu-fault drilling project (TCDP) hole-A as observed from geophysical logs. Geophys Res Lett 34:1-6

38. Zoback MD (2007) Reservoir geomechanics. Cambridge University Press, Cambridge

39. Zoback MD, Barton CA, Brudy M, Castillo DA, Finkbeiner T, Grollimund BR, Moos DB, Peska P, Ward CD, Wiprut DJ (2003)
Determination of stress orientation and magnitude in deep wells. Int J Rock Mech Min Sci 40:1049-1076

40. Zoback MD, Moos D, Mastin L, Anderson RN (1985) Wellbore breakouts and insitu stress. J Geophys Res 90:5523-5530

41. Zang A, Stephansson O (2010) Stress field of the earth's crust. Springer, Berlin

Publisher's Note Springer Nature remains neutral with regard to jurisdictional claims in published maps and institutional affiliations. 